تأثير محلول ياشى گياه مادرى با اسيد ساليسيليك و اسِرمين تحت تنش خشكى بر شاخصهاى جوانهزنى بذر سرخار گل (Echinacea purpurea)

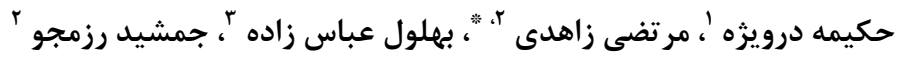

جكيده مبسوط

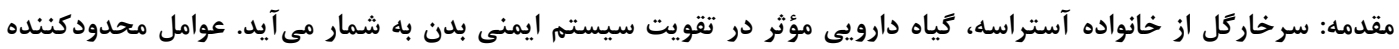

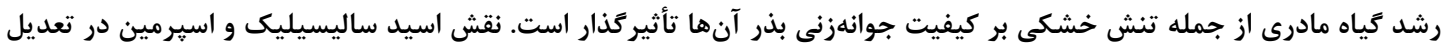

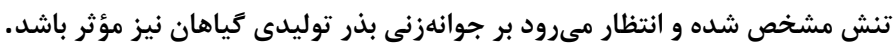

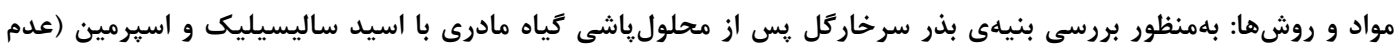

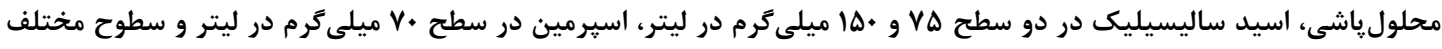

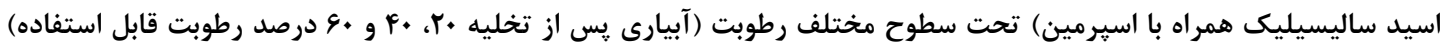

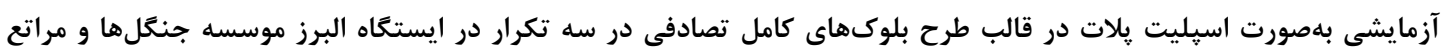

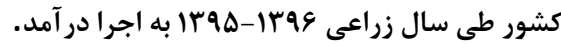

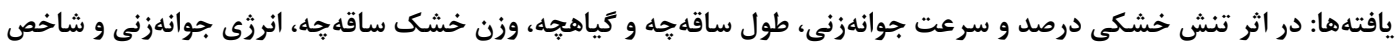

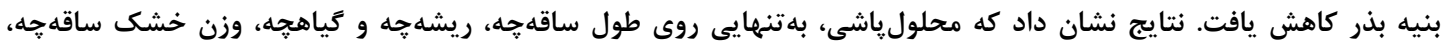

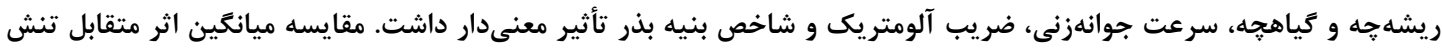

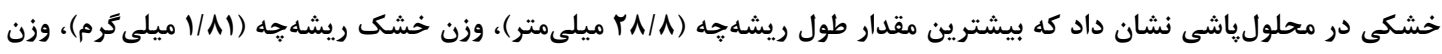

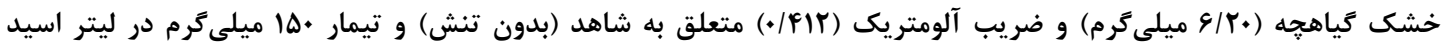

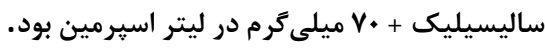

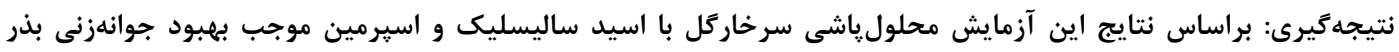

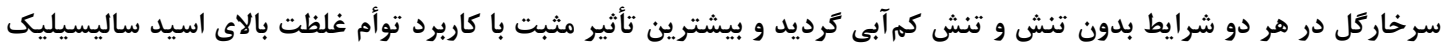

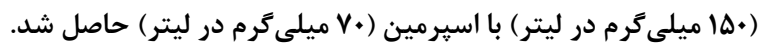
وازههاى كليدى: انرزى جوانهزنى، سرعت جوانهزنى، شاخص بنيه بذر، ضريب آلومتريك

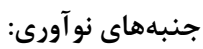

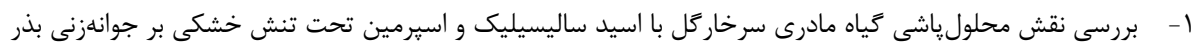

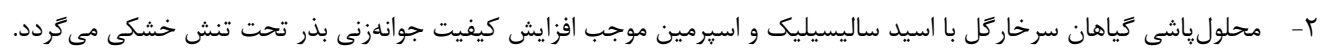




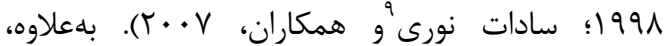
كياهجههاى ضعيف توليد شده در شرايط تنش از توان رقابتى پايينى براى مقابله با ساير عوامل از جمله

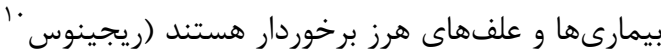

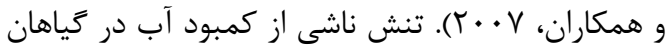

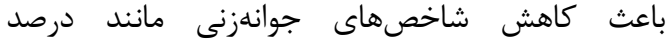

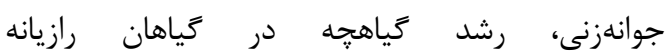
(عسكرى" (Foeniculum vulgare Mill)

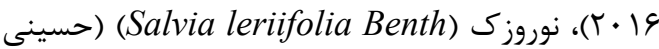

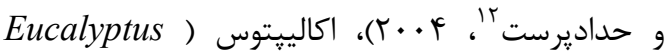
( globulus

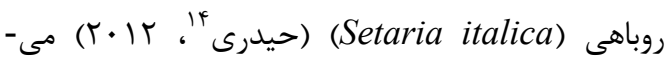

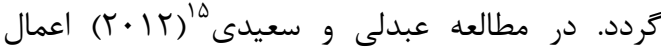
تنش خشكى بر كندم (Triticum aestivum L.) منجر به كاهش وزن و عملكرد دانه و برخى از مؤلفههاى

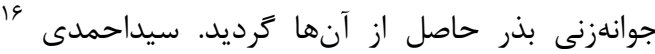

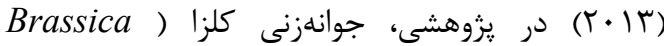
(napus در معرض تنش كرما و خشكى انتهايى فصل

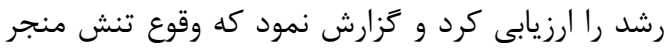

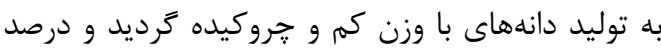
جوانهزنى و وزن خشك گياهجه بهعنوان معيارى از بنيه بذر مادرى كاهش يافت. بهعلاوه، تنش خشكى باعث كاهش صفاتى نظير درصد كياهجههاى طبيعى، طول و بادي

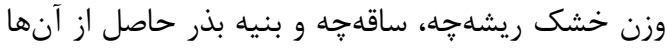

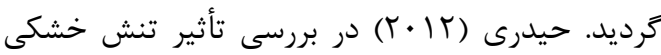

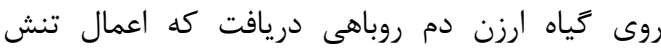

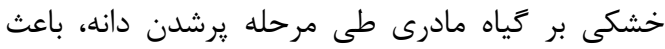

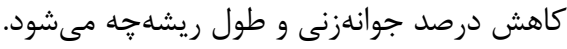
اسيد ساليسيليك يك تركيب فنولى است كه در درانئن تنظيم فرآيندهاى فيزيولوزيك كياه مانند القاى كلدهيى، رشد و نمو، جذب يونى، فتوسنتز، بسته شدن رئن روزنهانها،

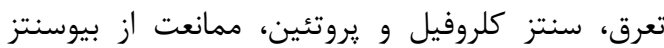

\footnotetext{
${ }^{9}$ Sadat Noori

${ }^{10}$ Riginos

${ }^{11}$ Askari

${ }^{12}$ Hosseini and Hadad Khodaparast

${ }^{13}$ Lopez

${ }^{14}$ Heidari

${ }^{15}$ Abdoli and Saeidi

${ }^{16}$ Seyed Ahmadi
}

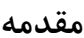

تقاضاى روزافزون به استفاده از خياهان دارويى در

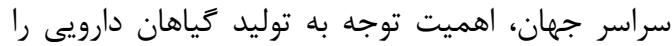
نشان مى نهد. سرخار كل (Echinacea purpurea L.) كياهى جندساله از تيره آستراسه' است كه كه كاربرد

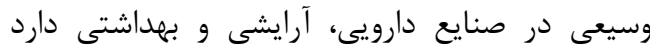

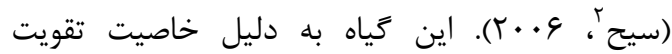
سيستم ايمنى بدن، بلمنظور بيشخيرى و و درمان بيمارىهاى مزمن ناشى از نقص קِاسخ ايمنى استفاده

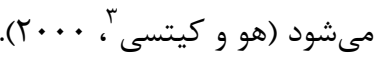
جوانهزنى و سبز شدن يكى از مهمهترين مراحل رشد

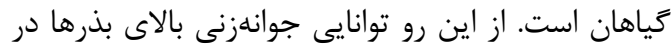
شرايط محيطى مختلف، احتمال استقرار بهتر كياه و وتاني

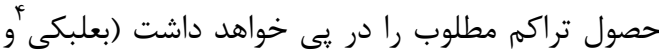

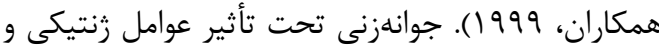

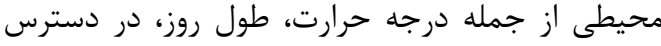
بودن آب و ميزان جذب مواد غذايى قرار مرار ميكيرد

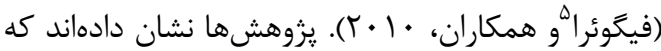
كياهان متعلق به يك كونه، جنانجه در محيطهايى با بان

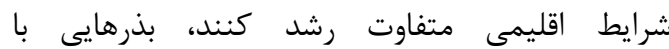
ويزگى هاى متفاوت از نظر واكنش به شرايط اقليمى إنى

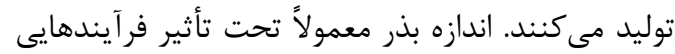
كه در زمان ير شدن دانه روى ريند مىشود، قرار مى گيرد و بر كيفيت بذر و نحوه استقرار

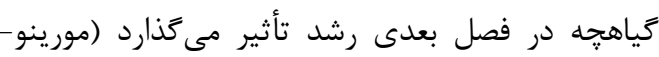

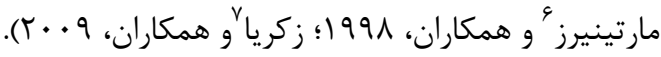
كمبود آب بهعنوان يك عامل محيطى مهمم رشد و

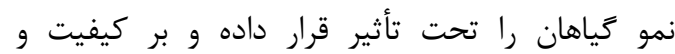

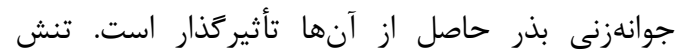
خشكى اعمال شده بر كياهان مادرى در زمان تشكيل دانه، بهدليل كاهش انتقال مواد فتوسنتزى به دانهان إنها، مى تواند سبب كاهش بنيه بذر شود (كيانى ^و همكاران،

\footnotetext{
${ }^{1}$ Asteraceae

${ }^{2}$ Ceeh

${ }^{3} \mathrm{Hu}$ and Kitts

${ }^{4}$ Baalibaki

${ }^{5}$ Figueroa

${ }^{6}$ Moreno-Martiners

${ }^{7}$ Zakaria

${ }^{8}$ Kiani
} 
(كافى و همكاران، · (Cnicus benedictus)

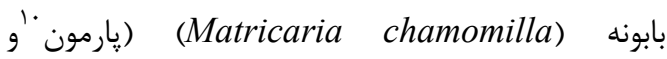

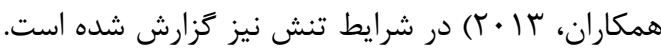

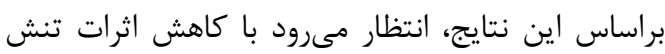

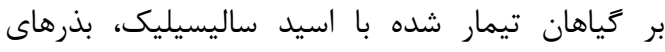
حاصله از شاخصهاى جوانهزنى بالاترى برخوردار باشند.

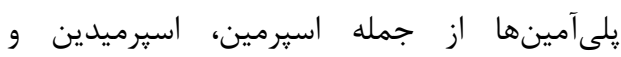
يوتريسين هيدروكربنهاى آلفاتيك با وزن مولكولى كمين

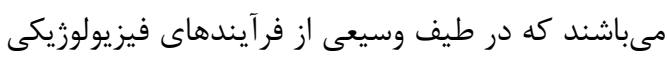

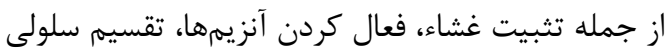

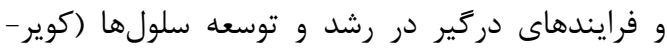

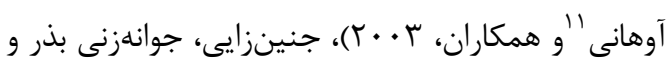

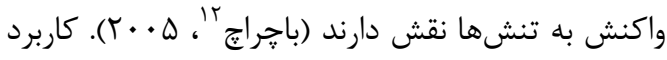

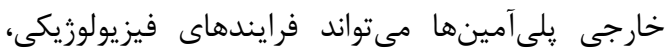

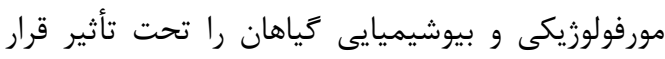

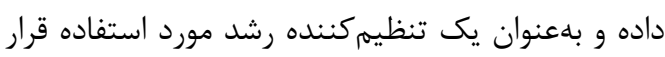

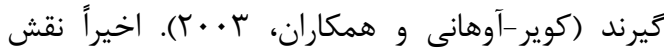

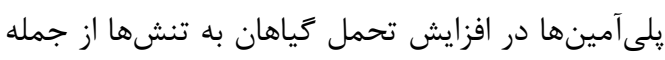

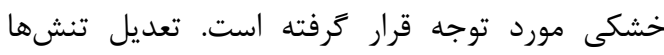

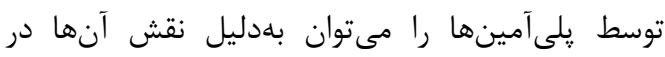

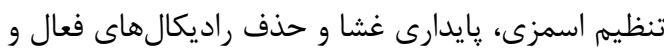

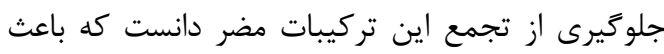

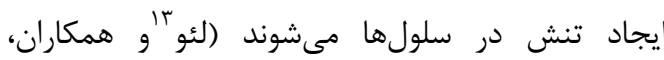

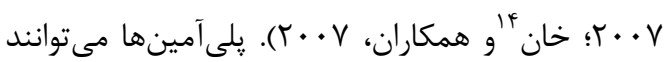

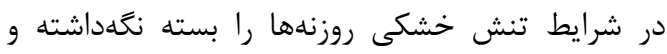

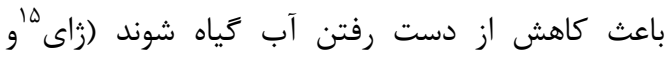

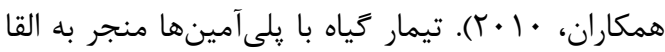

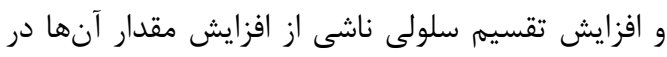

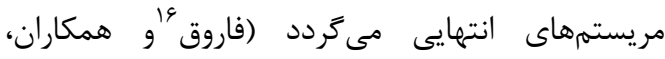

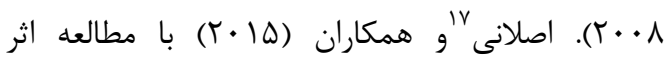

\footnotetext{
${ }^{9}$ Kafi

${ }^{10}$ Parmoon

${ }^{11}$ Kaur-awhney

${ }^{12}$ Bachrach

${ }^{13} \mathrm{Liu}$

${ }^{14}$ Khan

$15 \mathrm{Jie}$

${ }^{16}$ Farooq

${ }^{17}$ Aslani
}

اتيلن و افزايش وزن دانه و كيفيت جوانهزنى مؤثر

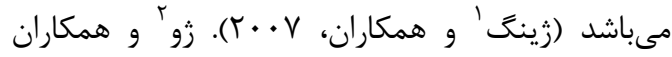
(999 (199 افزايش 9 درصدى وزن دانه را در اثر كاربرد اسيد ساليسيليك ناشى از انتقال بيشتر مواد فتوسنتزى به دانهها گزارش كردند. بهعلاوه، اسيد ساليسيليك لئي بهعنوان يك مولكول سيخنالى در ايجاد تحمل گياهان به طيف وسيعى از تنشهاى زنده و غيرزنده نقش

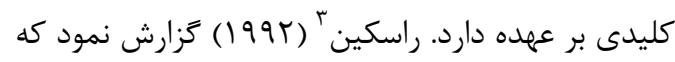

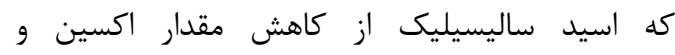
سيتوكنين در زياه جلوكيرى كرده و با افزايش سطح اسيد آبسيزيك در ريشه يك ريش تيش تطابق به تنش ايجاد

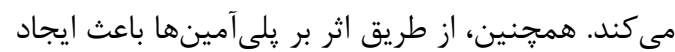

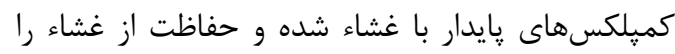
در شرايط تنش سبب مىشود. در :ثروهش كبيرى و

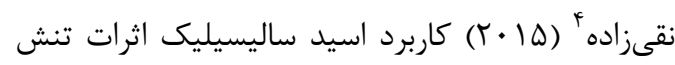
خشكى را كاهش و عملكرد بذر، محتواى نسبى آب برى

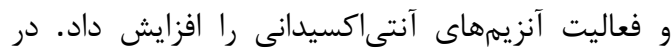

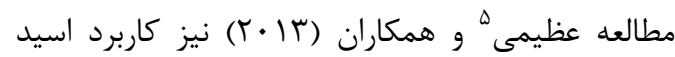
ساليسيليك باعث كاهش تنش خشكى در گَندم گرديد.

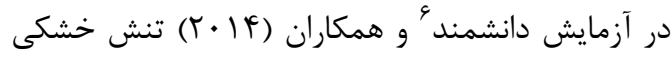
درصد، سرعت و متوسط زمان جوانهزنى، طول ريشهجه و ساقه ֶه و وزن خشك گياهجه را تحت تأثير قرار داد، ولى تيمار // • ميلى مولار اسيد ساليسليك باعث افزايش ون معنى دار كليه صفات و كاهش متوسط زمان جوانهزنى گرديد. در واقع تيمار زياهان با اسيد ساليسليك با تأثير

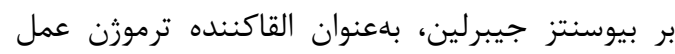

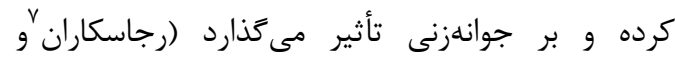

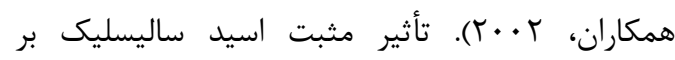
جوانهزنى ياهان آرابيدويسيس ( Arabidopsis ) (thaliana

\footnotetext{
${ }^{1}$ Jing

${ }^{2}$ Zhou

${ }^{3}$ Raskin

${ }^{4}$ Kabiri and Naghizadeh

${ }^{5}$ Azimi

${ }^{6}$ Daneshmand

${ }^{7}$ Rajasekaran

${ }^{8}$ Metwally
} 
همراه با اسيرمين) تحت سطوح مختلف رطوبت (آبيارى

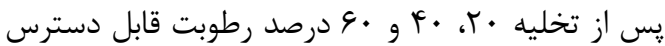

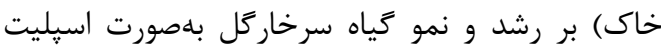
يلات در قالب طرح بلوكهاى كامل تصادفى در ب تكرار در مزرعه تحقيقاتى موسسه تحقيقات جنگل ها و مراتع

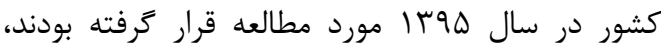

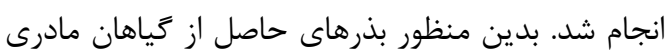
در مزرعه برداشت شده و براى انجام آزمايش جوانهزنى

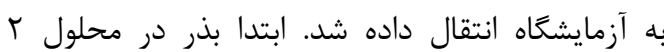

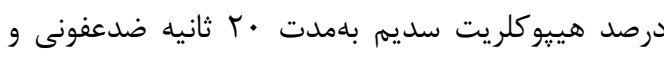
با آب مقطر شستشو شدند. سيس از هر تيمار تعداد ها ها

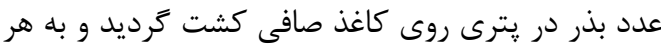

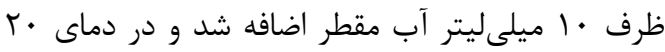
درجه سانتى تعداد بذرهاى جوانهزده از روز جهارم (شمارش اوليه) تا روز بيست و يكم (شمارش نهايى) بهصورت روزانه در

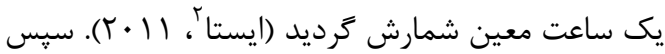

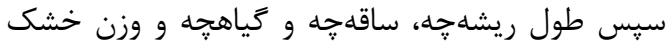

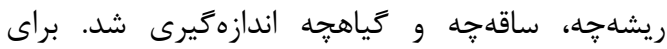

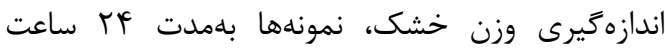

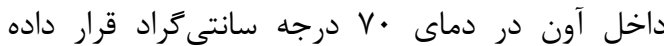
شدند. سيس با استفاده از روابط ا تا ه، صفات سرعت

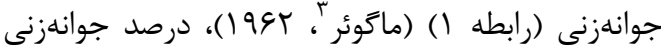

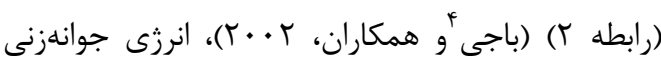

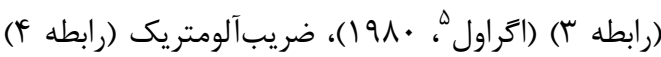

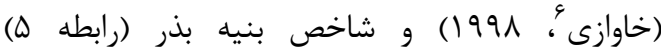

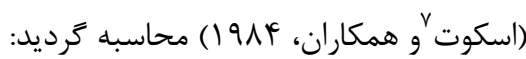
رابطه (1) (1) (1) $\mathrm{GR}=\sum \mathrm{N}_{\mathrm{i}} / \mathrm{T}_{\mathrm{i}}$

GR

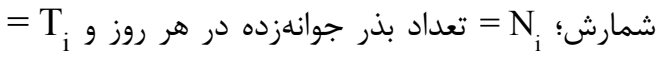
شمارش روز يس از شروع آزمايش.

رابطه ז:

\footnotetext{
2 ISTA

${ }^{3}$ Maguire

${ }^{4}$ Bajji

${ }^{5}$ Agrawal

${ }^{6}$ Khavazeh

${ }^{7}$ Scott
}

اسيرميدين در هجهار غلظت (صفر، |/•، ه/• و 1 ميلىمولار) بر ارقام خيار تحت تنش دريافتند كه تيمار 1/ • ميلىمولار اسيرميدين باعث افزايش درصد جوانه-

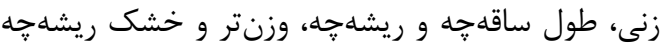
در رقم رشيد گرديد؛ ولى تيمار 1 ميلىمولار اثر بازدارندگى بر فاكتورهاى جوانهزنى اين رقم داشت. نتايج

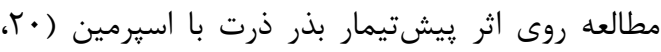

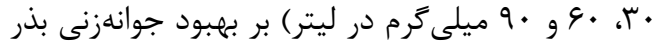
و فعاليت آنزيمى در شرايط تنش نشان داد كه كاربرد يلى آمين با غلظت ·و ميلى گترم در مقايسه با ساير

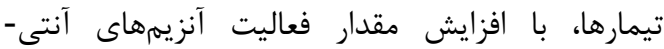
اكسيدانى، مقاومت گَياهان در مقابل تنش را افزايش داده و باعث بهبود جوانهزنى بذر مىشوند (ساعدنزاد' و و همكاران، اعمال تنش خشكى بر زياهان مادرى در شرايط مزرعه مىتواند اثرات نامطلوبى بر بنيه و شاخصهاى جوانهزنى و نيز رشد گياهجههاى حاصل از بذر آنها داشته باشد. در سالهاى اخير براى افزايش تحمل كَياهان و كاهش اثرات منفى تنش خشكى، كاربرد خارجى برخى تنظيمكنندهاى ر رشد مانند اسيد ساليسيليك و اسيرمين افزايش يافته است. بعلاوه، ميزان جوانهزنى بذر در تعيين تراكم نهايى گياه حائز اهميت است و تراكم مطلوب با كاشت بذرهاى با بنيه مناسب بدري

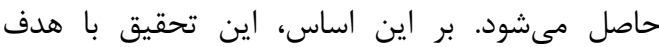
ارزيابى تأثير تنش خشكى و و محلولياشى اسيد

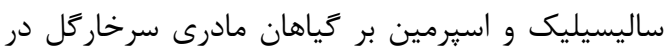
مزرعه بر شاخصهاى جوانهزنى بذر حاصل از آنها انجام

\section{مواد و روشها}

اين تحقيق جهت ارزيابى مؤلفههاى جوانهزنى بذر حاصل از زياهان سرخارگل كه قبلاً در يك آزيق آزمايش

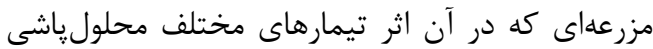
و و و Vدم محلولياشى، اسيد ساليسيليك در دو سطح

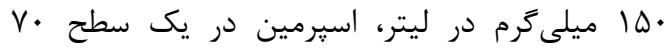

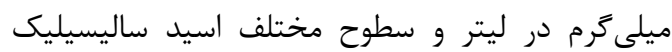

\footnotetext{
${ }^{1}$ Saeidnejad
} 
رطوبت درصد كاهش در اثر تنش در طول ريشهجه

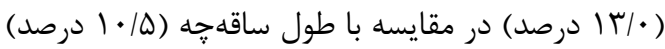

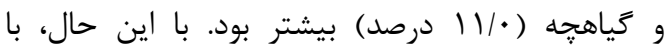

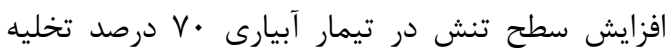

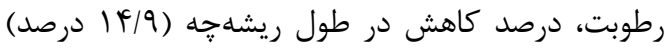

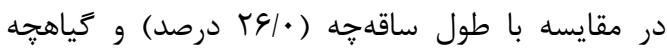

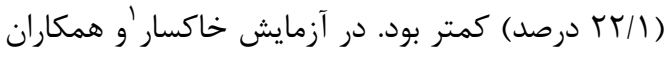

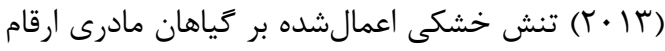

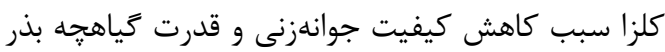

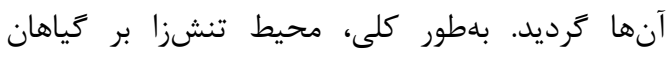

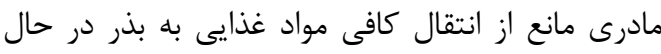

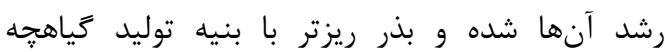
ضعيفترى تشكيل مىشوند (رجينوس و وندر همكاران،

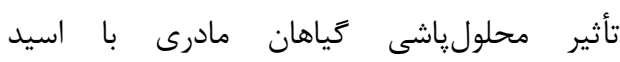

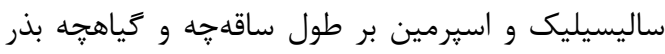
جوانهزده آنها در سطح احتمال خطاى يكى دريك برد

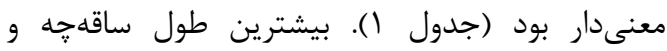

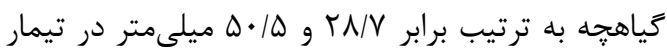

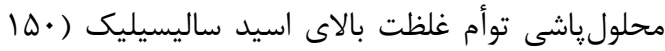

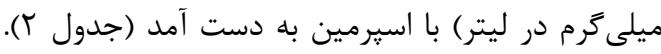

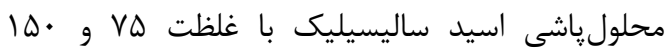

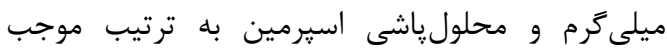

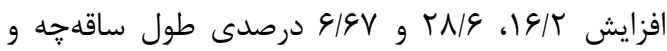

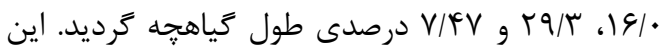

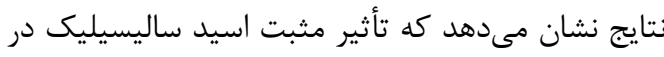

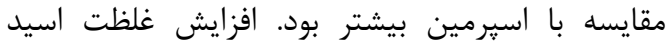

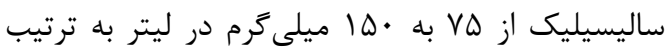

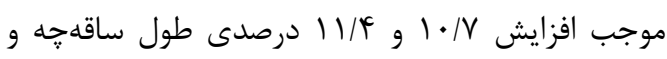

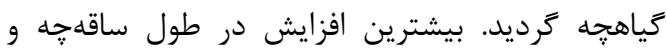

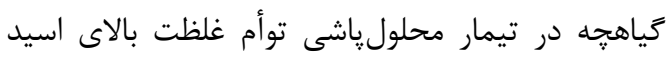

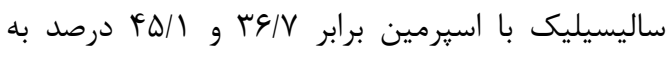

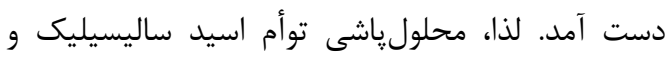

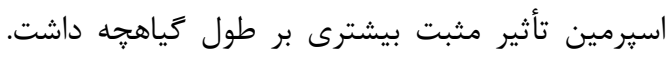
كاربرد اسيد ساليسيليك و اسبرمين مىتواند فيت فعاليت

\footnotetext{
${ }^{1}$ Khaksar
}

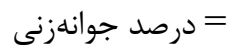

• • × (جوانهزده بذرهاى تعداد )/(بذرها كل تعداد)

رابطه سّ:

درصد بذرهاى جوانهزده در يك روز = انرزى جوانهزنى

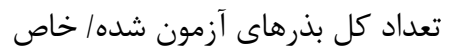

رابطه ث:

ميانكَين وزن خشك ريشهجه) =ضريب آلومتريك (ميانگين وزن خشك ساقهاهه|

رابطه ه:

=

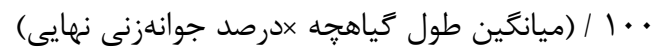

تجزيه و تحليل آمارى

تجزيه آمارى دادهها توسط نرمافزار

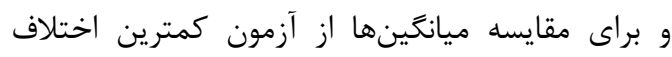
معنى دار (LSD) استفاده كرديد.

نتايج و بحث

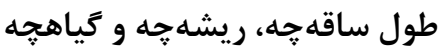

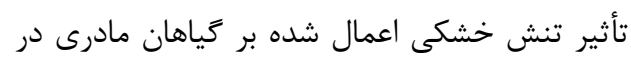

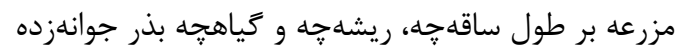

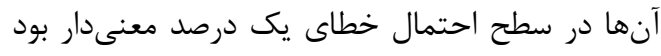

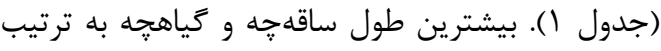

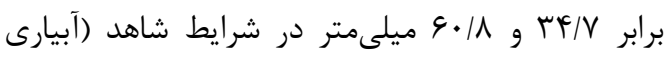

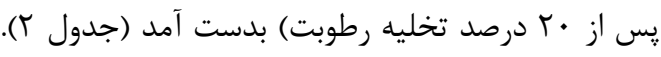

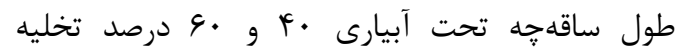

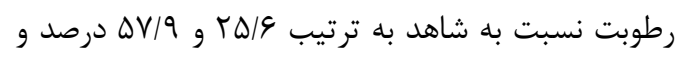
طول Fياهجه

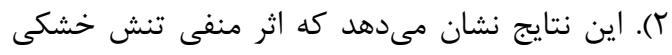

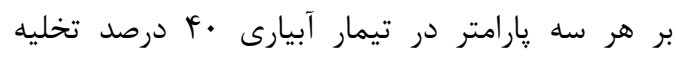

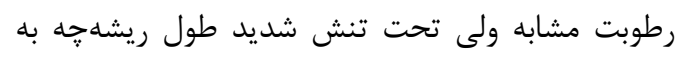

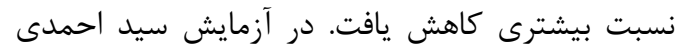

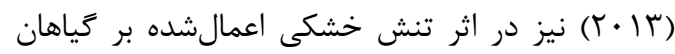

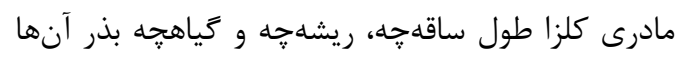
كاهش يافت. در مطالعه ايشان در تيمار آبيارى براساس

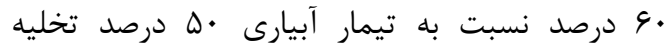


اسيرمين فقط در سطح شديد تنش از تيمار شاهد بيشتر

وزن خشك ساقهجه، ريشه קه و گَياهجه

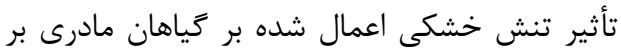
وزن خشك ساقهجه بذرهاى جوانهزده آنها در سطح

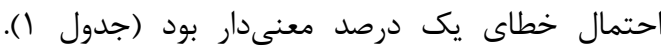

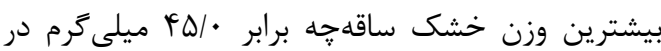

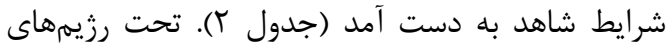

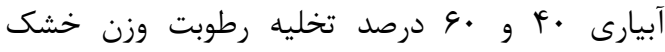

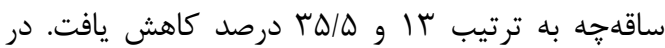

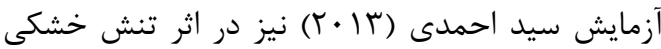

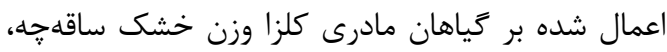

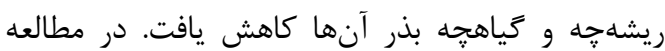
ايشان در هر دو تيمار آبيارى •و و •V درصد تخليه رطوبت نسبت به شاهد (•0 درصد تخليه رطوبت)، درصد كاهش در وزن خشك ريشهجه (FT/Y درصد) در اثر تنش خشكى در مقايسه با وزن خشك

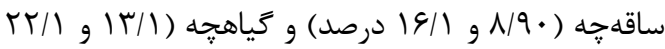

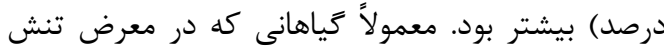
خشكى قرار مى گيرند بذرى توليد مى كنند كه داراى

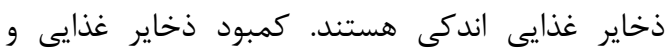
كاهش كارايى تبديل ذخاير به بافت كياهجه از جمله

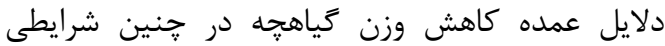

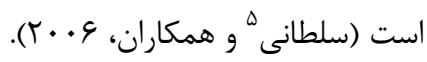

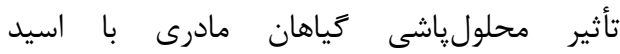
ساليسيليك و اسيرمين بر وزن خشك ساقهجه بذرهاى جوانهزده آنها در سطح احتمال خطاى يكى درصد معنىدار بود (جدول ()). بيشترين وزن خشك ساقهجه برابر M/99 ميلى

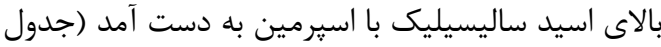

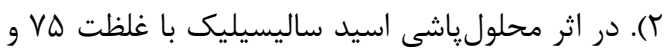

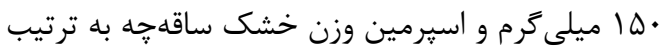

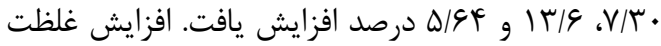
اسيد ساليسيليك از VD به •lQ ميلى موجب افزايش ه/AN درصدى وزن خشك ساقه كرديد. بيشترين ميزان افزايش در وزن خشك ساقهجه

${ }^{5}$ Soltani
آنزيمهاى آنتىاكسيدانى را افزايش داده و از طريق

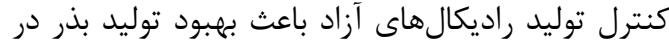

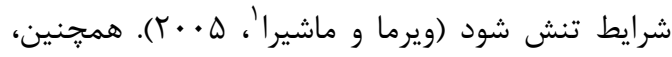
اسيد ساليسيليك تأثير مثبت بر فتوسنتز و فعاليت آنزيمهاى نيترات رداكتاز و كربنيك آنهيدراز دارد كه موجب افزايش انتقال مواد فتوسنتزى به دانهها مىشود

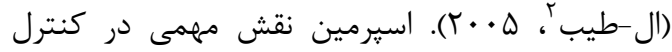
تقسيم سلولى ريشه، تشكيل ريشه اوليه و ريشهائ

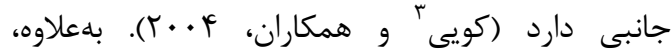
اسيرمين از طريق كاهش ميزان تعرق، افزايش فتوسنتز و تنظيم اسمزى باعث بهبود رشد زياهان در شرايط

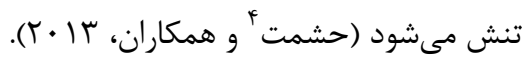

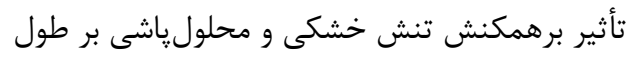
ريشهجه در سطح احتمال خطاى يك درصد معنى دار

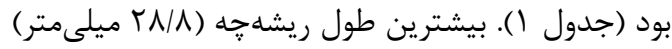
در اثر محلولياشى توأم غلظت بالاى اسيد سيد ساليسيليك

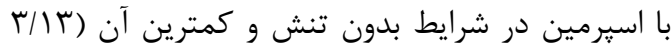
ميلىمتر) در تيمار محلولياشى نشده در شرايط تنش

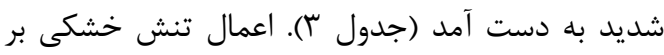

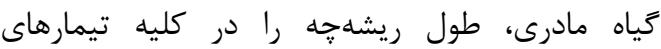
محلولياشى كاهش داد. بيشترين درصد كاهش در طول

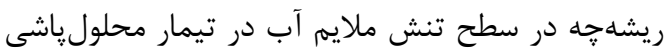

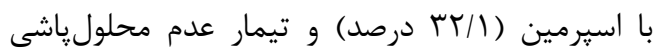
(M/9/9 درصد) و در سطح شديد تنش در تيمار عدم

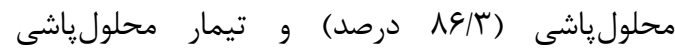

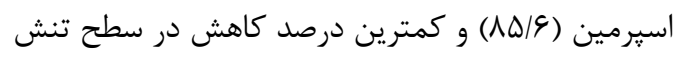
ملايم (T/T د درصد) در تيمار محلولياشى توأم اسيد ساليسيليك با اسيرمين و در سطح تنش شديد (9/9)

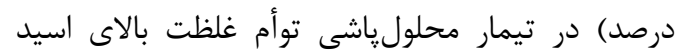

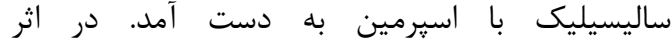

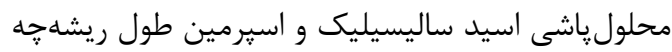
افزايش و ميزان تأثير محلولياشى اسيد ساليسيليك به-

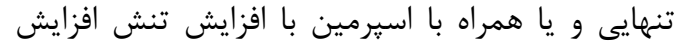

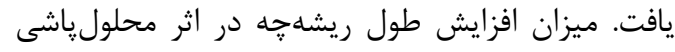

\footnotetext{
${ }^{1}$ Verma and Mishra

${ }^{2}$ EL-Tayeb

${ }^{3}$ Couee

${ }^{4}$ Heshmat
} 


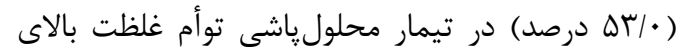

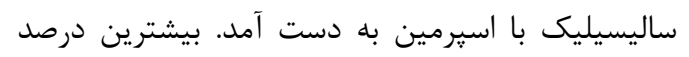

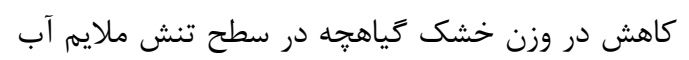

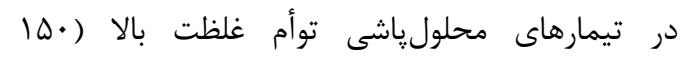
ميلى

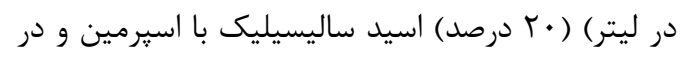

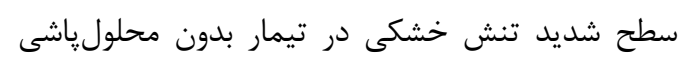
( )

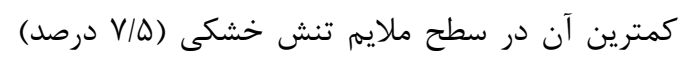

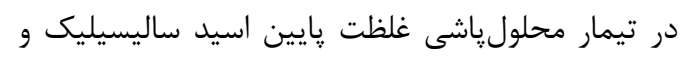
در سطح شديد تنش خشكى (\&/\& در درصد) در تيمار

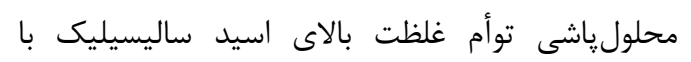

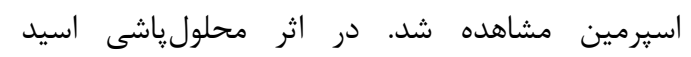

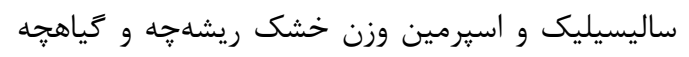

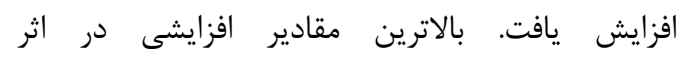
محلولياشى اسيد ساليسيليك بلهنهايى و يا همراه بانيا

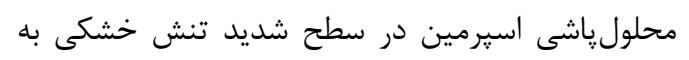

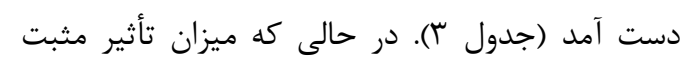

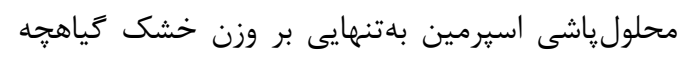
در هر دو سطح تنش خشكى در مقايسه با تيمار آبيارى

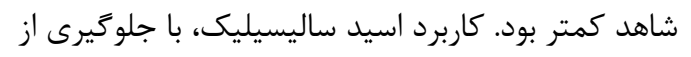

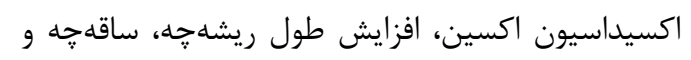

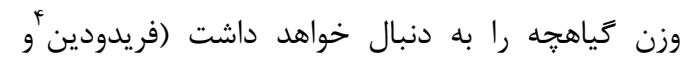

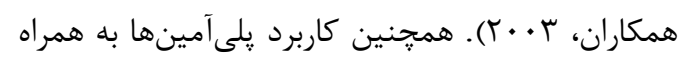

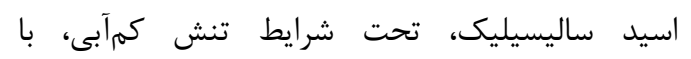

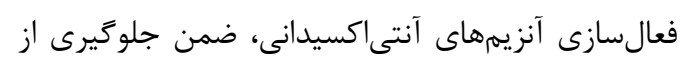

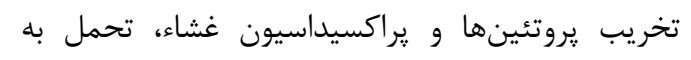

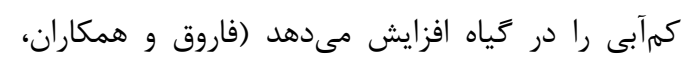

\section{درصد و سرعت جوانهزنى}

تأثير تنش خشكى اعمال شده بر كياهان مادرى بر

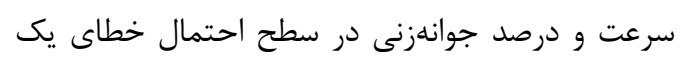

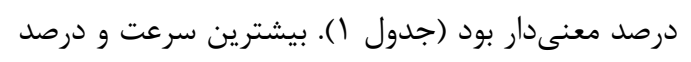

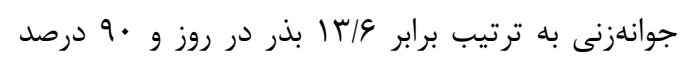

\footnotetext{
${ }^{4}$ Fariduddin
}

در تيمار محلولياشى توأم غلظت بالاى اسيد

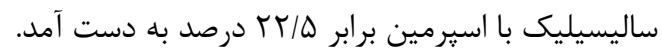
با توجه به اينكه تنش خشكى باعث كاهش فعاليت

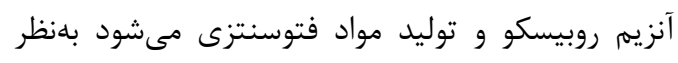

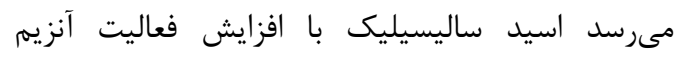
روبيسكو و بهبود فتوسنتز سبب افزايش رشد رياه مىشود. بعلاوه، نقش اسيد ساليسيليك بر رشد زياهان تحت تنش به تأثير آن بر جذب عناصر نيز نسبت داده

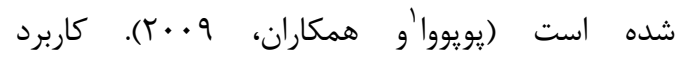
يلى آمينها، تحت شرايط تنش كمآبى باعث فعالسازى آنى

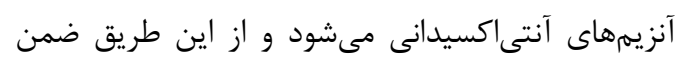
جلوگيرى از تخريب يروتئينها و يراكسيداسيون غشاء،

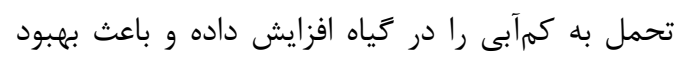

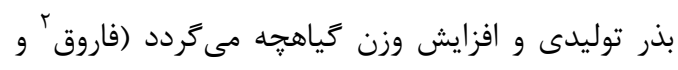

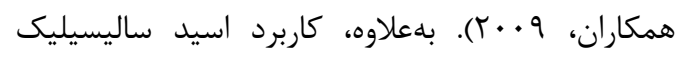

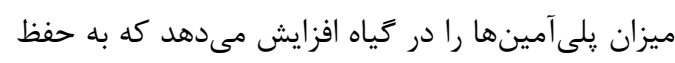
غشا كه موجب بهبود رشد كياه و توليد بذر با كيفيت بالاتر تحت شرايط تنش خشكى مىشود، كمك مى كند

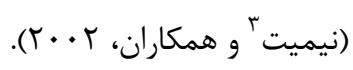
تأثير برهمكنش تنش خشكى و محلولياشى بر وزن

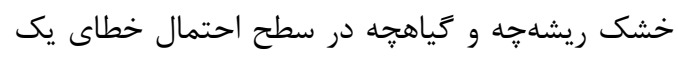
درصد معنى دار بود (جدول ()). در اثر اعمال تنش ردئ

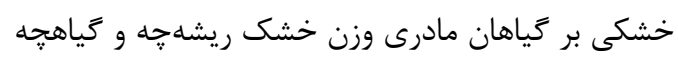

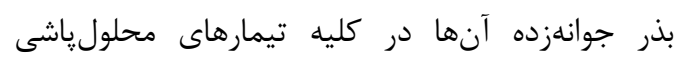

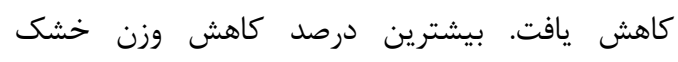

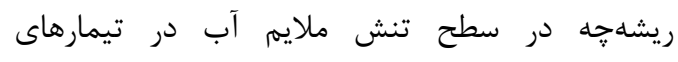

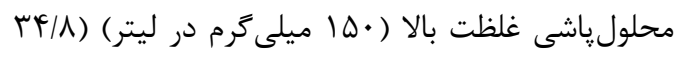

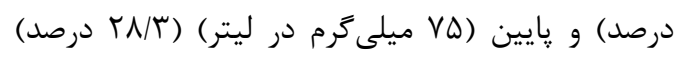

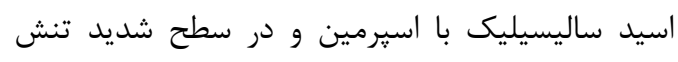
خشكى در تيمار بدون محلولياشى (س/19 درصد) و در

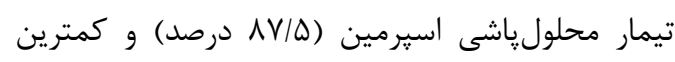
درصد كاهش در سطح ملايم تنش خشكى (I/D/ درصد) در تيمار محلولياشى توأم غلظت يايين اسيد

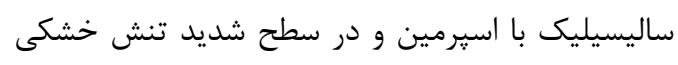

\footnotetext{
${ }^{1}$ Popova

${ }^{2}$ Farooq

${ }^{3}$ Nemeth
} 


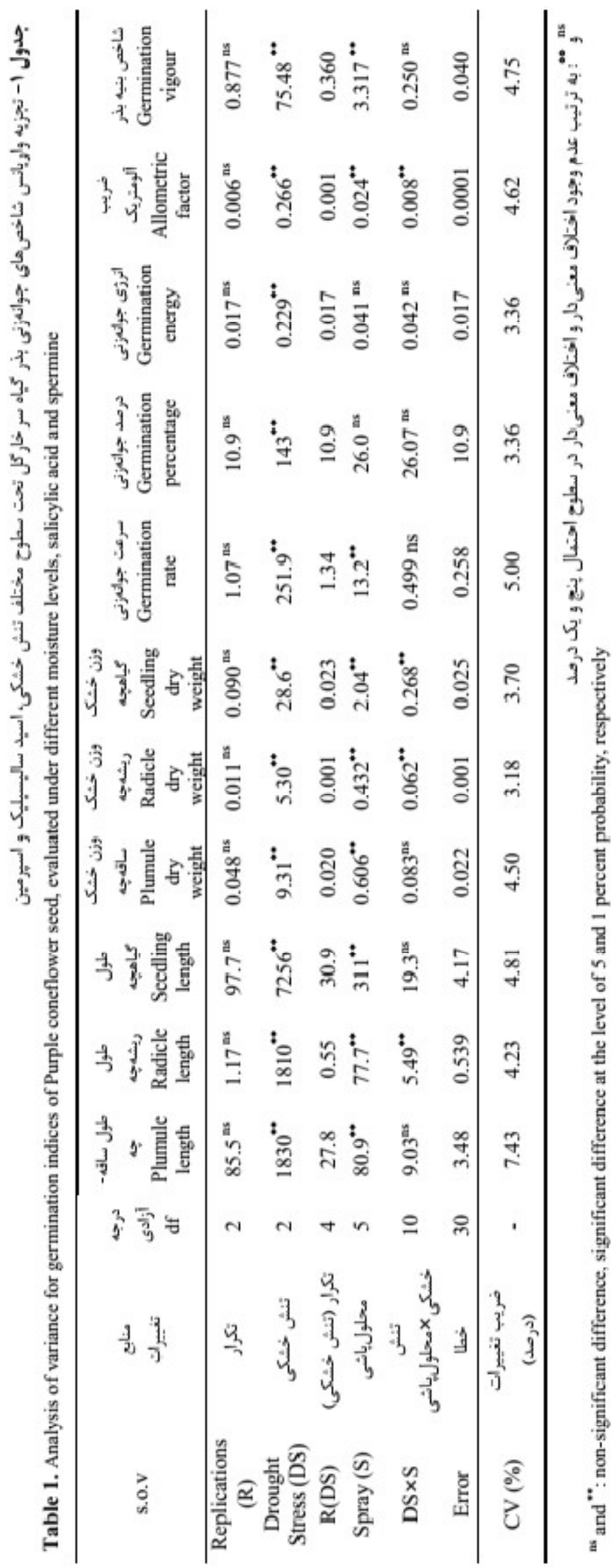


اندازه بذر توليد شده را به دنبال داشت و بذر داراى ذخاير غذايى بيشتر، از سرعت جوانهزنى بالاترى لدرى

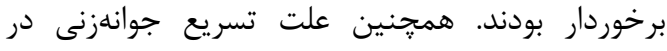
بذرهاى تيمار شده با دو تركيب فوق مىتواند بهاعلت افزايش فعاليت آنزيمهاى تجزيهكننده مثل آلفا آميلاز، افزايش سطح شارز انرزى زيستى در قالب افزايش مقدار

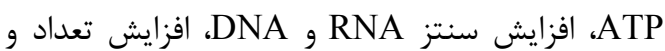
ارتقا عملكرد ميتوكندرى باشد. در واقع بخشى از

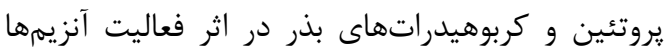

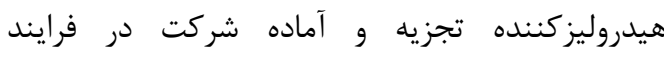
جوانهزنى مىشوند؛ كه مىتواند توجيهى براى تسريع سرعت جوانهزنى و كاهش متوسط زمان جوانهزنى باشد

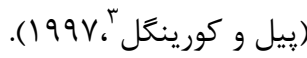

انرزى جوانهزنى، ضريب آلومتريك و شاخص بنيه

تأثير تنش خشكى اعمال شده بر زياهان مادرى بر

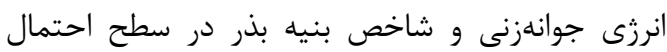
خطاى يك درصد معنى دار بود (جدول (). بيشترين انرزى جوانهزنى و شاخص بنيه بذر به ترتيب برابر أ و وردئ

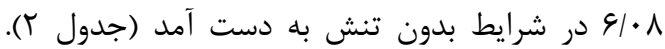

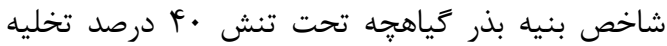
رطوبت نسبت به شاهد Td/F درصد كاهش نشان داد

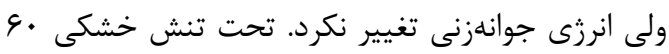

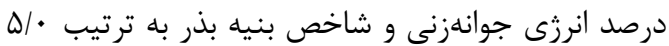

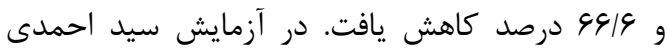

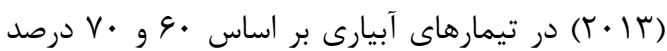
نسبت به تيمار •ه درصد تخليه رطوبت، در اثر تنش خشكى اعمالشده بر كياهان مادرى كلزا، ضريب دران

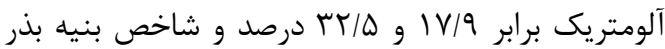

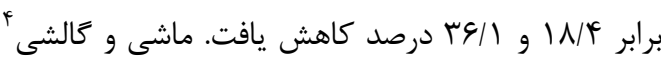

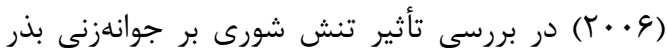

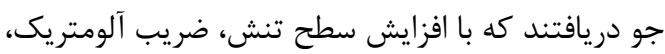

${ }^{3}$ Pill and Korengle

${ }^{4}$ Mashi and Galeshi
در تنش خشكى شاهد به دست آمد (جدول ؟). سرعت

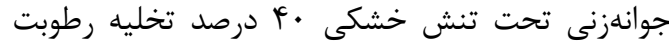

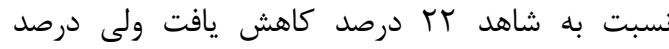
جوانهزنى تغييرى نكرد. تحت تنش •4 درصد تخليه رطوبت درصد و سرعت جوانهزنى به ترتيب درصد كاهش يافت. لذا، تنش خشكى اعمال شده بر

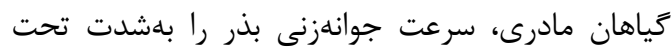

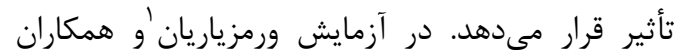

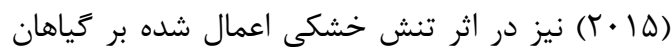

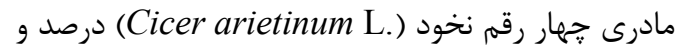

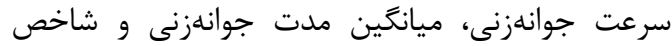
بنيه كياهجه بذر حاصل از آنها كاهش يافت؛ همدرنين

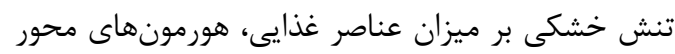
جنينى، فتوسنتز و آمادهسازى كياهان تأثير داشته و از ازئ

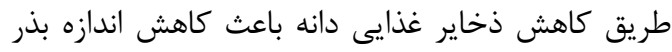

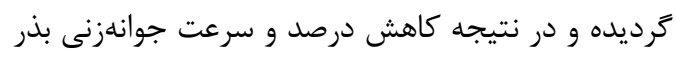

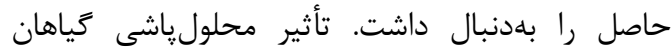
مادرى با اسيد ساليسيليك و اسيرمين بر سرعت بران جوانهزنى در سطح احتمال خطاى يكى درصد معنى اليد اليكار

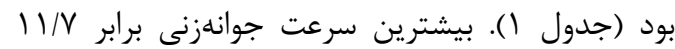

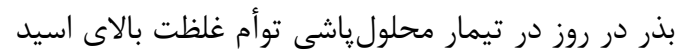

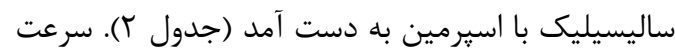
جوانهزنى در اثر محلول ياشى اسيد ساليسيليك با غلظت و و • VD هم

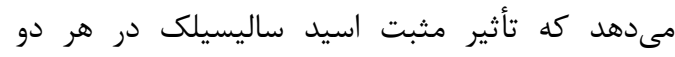
غلظت بكار برده شده در مقايسه با اسيرمين بيشتر بود. بيشترين ميزان افزايش در سرعت جوانهزنى در تيمار

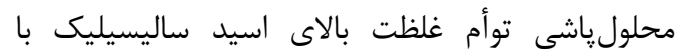

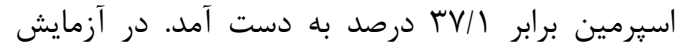

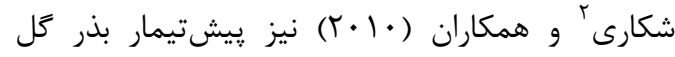

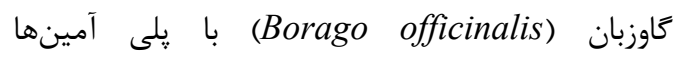

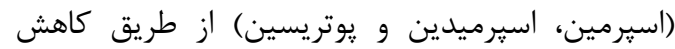

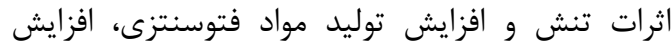

\footnotetext{
${ }^{1}$ Warmazyaryan

${ }^{2}$ Shekari
} 
غلظت بالاى اسيد ساليسيليك با اسيرمين برابر fQ/9 درصد به دست آمد.

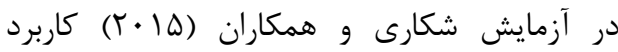
هلى آمينها (يوتريسين، اسِرميدين و اسيرمين) از طريق

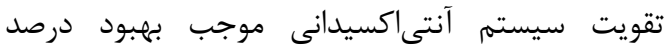
جوانهزنى، انرزى جوانهزنى و شاخص بنيه بذر زئه

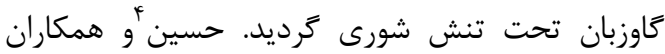

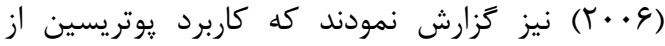
طريق افزايش طول ساقه داده و باعث ايجاد مقاومت در برابر تنش مى مى طردد. تأثير

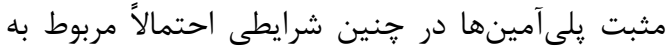

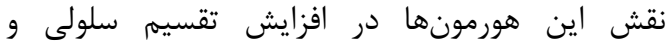
هورمونهاى گياهى از قبيل اكسين و جيبرلين و كاهش آبسيزيك اسيد در يايه مادرى مىباشد كه بهدنبال آن

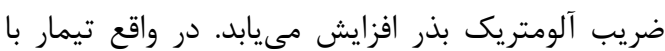
يلى آمينها موجب بهحداقل رساندن آسيب سلو سلى مىشود. تيمار كردن يايه مادرى احتمالاً باعثترمينم غشاى آسيبديده بذر و تغييرات در رشد محور جنينى و

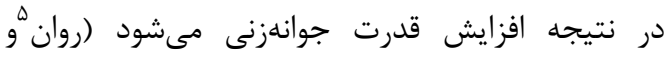

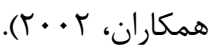
تأثير برهمكنش تنش خشكى و و محلولياشى بر ضريب آلومتريك در سطح احتمال خطاى يك درصد

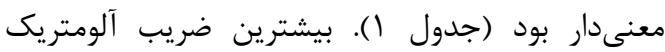

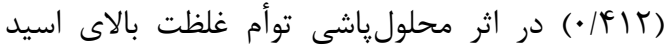
ساليسيليك با اسيرمين در تنش خشكى شاهد به دست

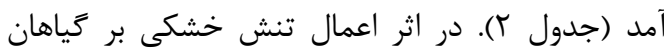
مادرى ضريب آلومتريك بذرهاى جوانهزده آنها كاهش يافت. بيشترين درصد كاهش (9/.r درصد) در سطح تنش ملايم آب در تيمار محلولياشى توأم غلظت دين بالاى اسيد ساليسيليك با اسيرمين و در تنش شديد در تيمار بدون محلولياشى (9/ •9 درصد) و كمترين آن در سطح

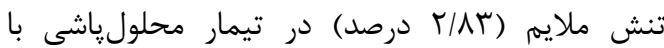
اسيرمين و در سطح تنش شديد (r/Tس درصد) در تيمار محلولياشى توأم غلظت بالاى اسيد ساليسيليك با نئن سيرمين به دست آمد. (جدول ب). بالاترين مقادير افزايشى در اثر محلوليّاشى اسيد ساليسيليك بهتنهايى لهيى

\footnotetext{
${ }^{4}$ Hussein
}

${ }^{5}$ Ruan
به علت تغيير در تخصيص مواد بين ريشهجه و اندامهاى هوايى كاهش مي يابد.

گياهان براى تحمل تنشهاى خشكى و شورى نياز به تنظيم اسمزى دارند و يكى از راههاى آن توليد مواد

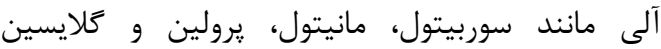
مىباشد. ساخت اين مواد براى زياهان با صرف انرزى مانى

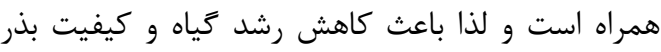

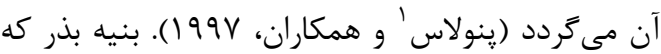
نشاندهنده ميزان توان يك بذر براى توليد گياهجهـهاى

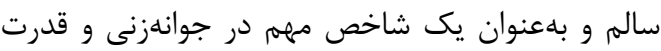

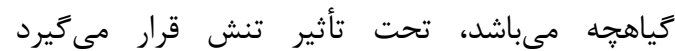

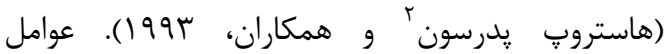
بر شاخص بنيه بذر اثر دارند كه مهرمترين آنها ساختار

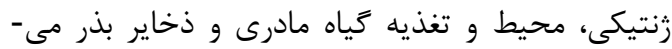
باشند. تنش خشكى از طريق كاهش ضريب آلومتريك بـ بـ باعث كاهش بنيه بذر مىشود. در واقع تنش با تحت

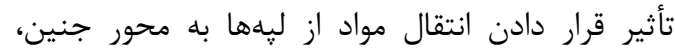
سرعت رشد محور جنين را كاهش و با جلو

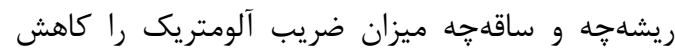

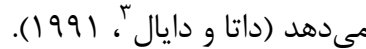

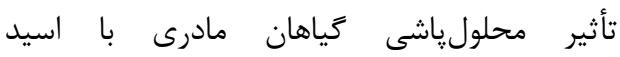
ساليسيليك و اسيرمين بر شاخص بنيه بذر در سطح احتمال خطاى يك درصد معنى دار بود (جدول (1).

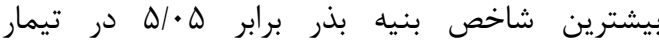

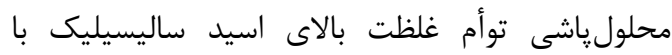

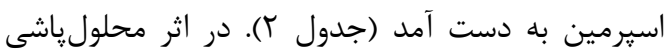
گياهان مادرى با اسيد ساليسيليك و اسيرمين، شاخص بنيه بذر افزايش يافت. شاخص بنيه بذر با غلظت ول و و

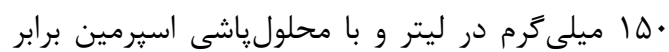

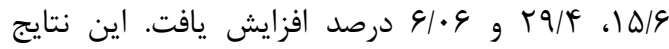
نشان مىدهد كه تأثير مثبت اسيد ساليسيليك در مقايسه با اسِرمين بيشتر بود. افزايش غلظت اسيد إنديد

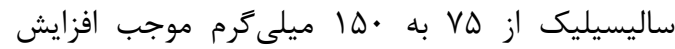
NN/K درصدى شاخص بنيه بذر گرديد. بيشترين ميزان افزايش در شاخص بنيه بذر در تيمار محلولياشى توأم

\footnotetext{
${ }^{1}$ Penuelas

${ }^{2}$ Hasstrup Pedersen

${ }^{3}$ Datta and Dayal
} 


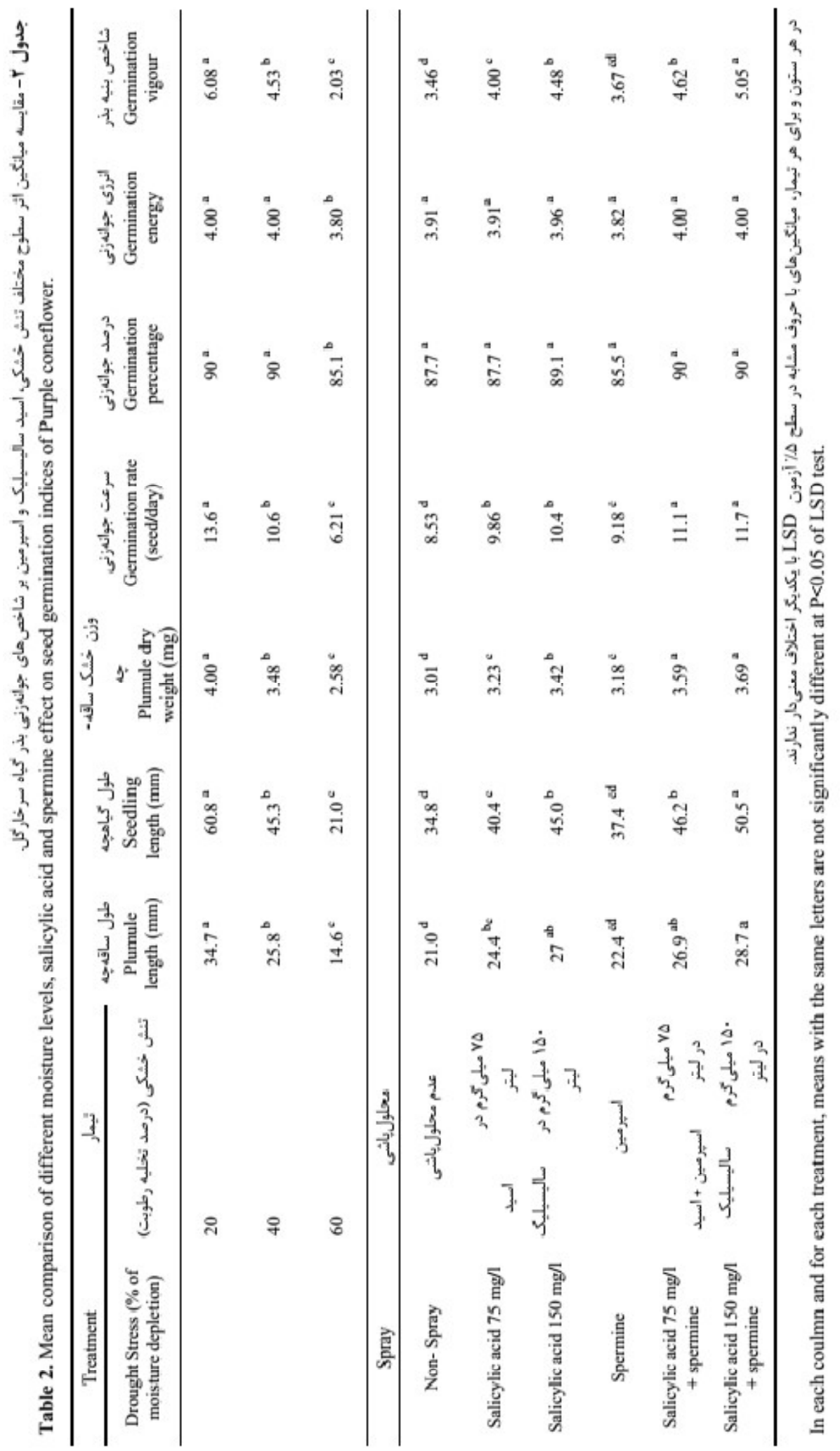




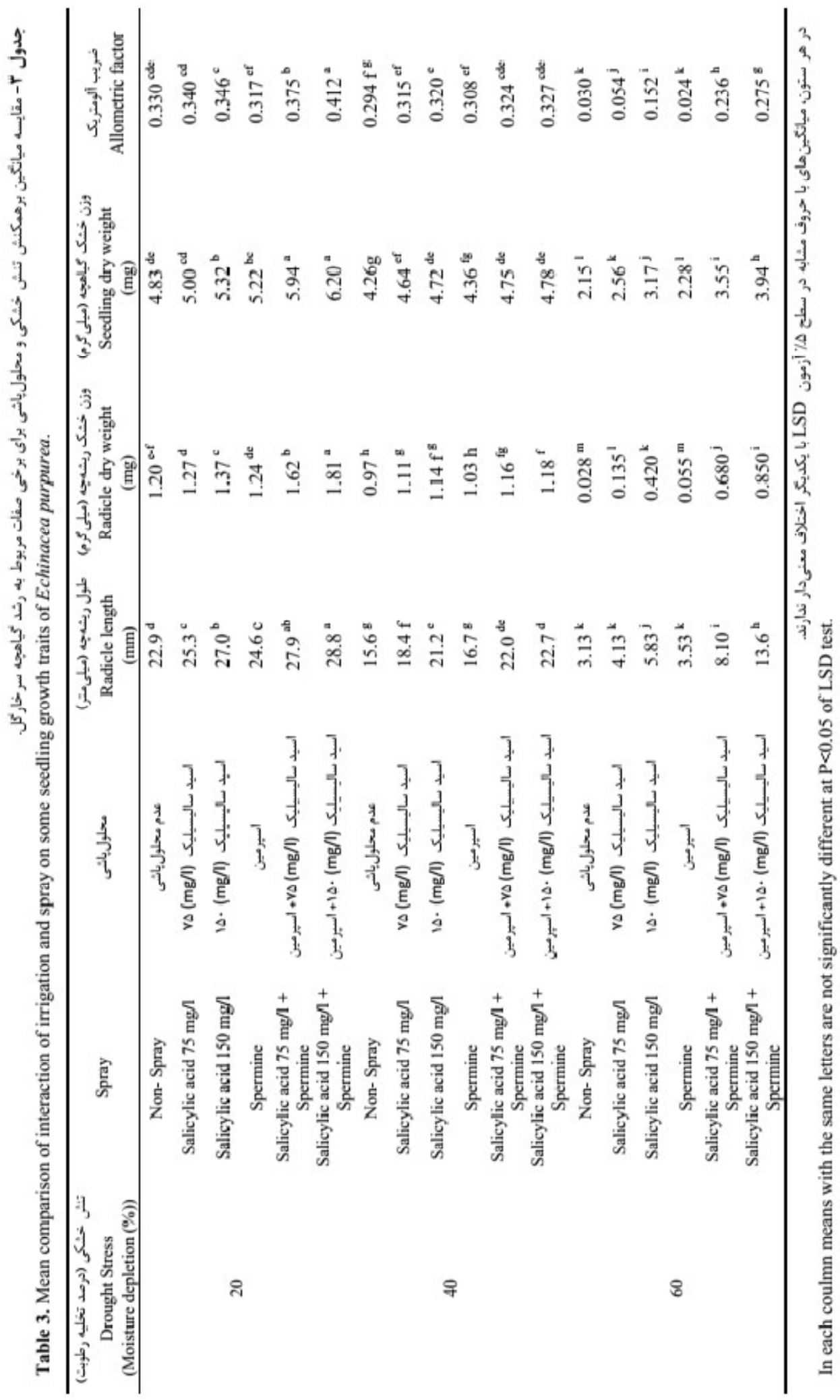


كيفيت جوانهزنى بذر آنها گَرديد و محلولياشى غلظت بالاى اسيد ساليسيليك با اسيرمين بيشترين اثر مثبت راني

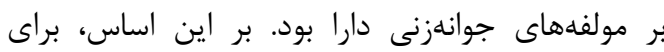

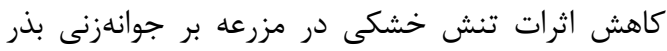

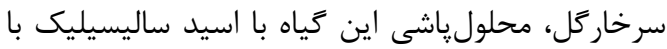

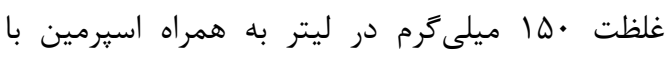
غلظت • V ميلى كرم در ليتر توصيه مى لوشود.

\section{سياسگزارى}

بدين وسيله از كاركنان محترم ايستخاه البرز موسسه

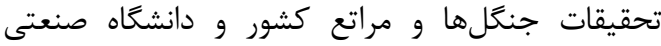
اصفهان، بلواسطه همكارى ايشان و فراهم آوردن شرايط آنات لازم جهت اجراى اين بزوهش سياسگزارى مىشود.
و يا همراه با اسيرمين در سطح شديد تنش خشكى به دست آمد. با اين حال، ميزان افزايش ضريب آلومتريك سيد

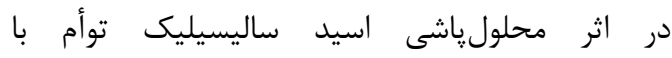
محلولياشى اسيرمين در سطح ملايم تنش در مقايسه

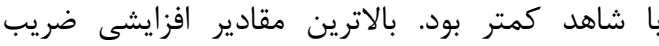
آلومتريك در اثر محلولياشى اسيرمين در سطح تنش

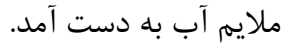
به نظر مىرسد تيمار گَياهان با اسيد ساليسيليك و اسيرمين، به دليل فعالسازى فعاليت متابوليكى، مانند

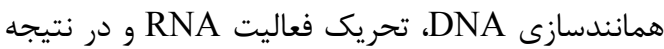
افزايش ميزان يروتئينسازى، ترميم غشاى سلولى آسيب ديده و توليد هورمونهاى تحريك كننده جوانهزني، باعث

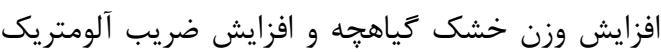
مىشود (جوجونوواسكى و كومى'، 1997). افزايش معنى دار ضريب آلومتريك تحت تأثير محلولياشى، بيان كننده اين مطلب است كه رشد ساقهجه در مقايسه با ريشهجه به كاهش ريتانسيل آب حساستر بوده و

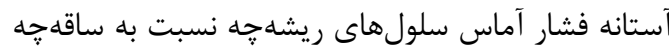

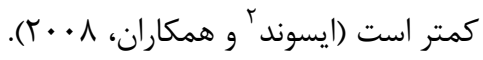

نتيجه

در اين يزوهش، اعمال تنش خشكى بر كياهان

مادرى سرخارگل تأثير منفى و محلولياشى اين كَّلياهان

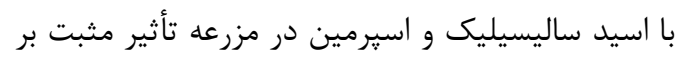

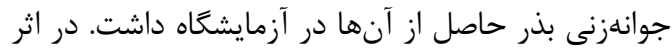

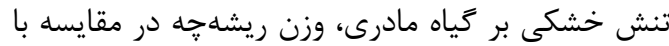

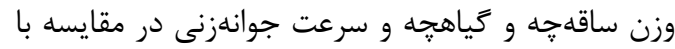
درصد جوانهزنى به نسبت بيشترى كاهش يافت. همجنين تنش خشكى اعمال شده در مزرعه بر كياه مادرى بر شاخص بنيه بذر در مقايسه با انرزى جوانهزنى

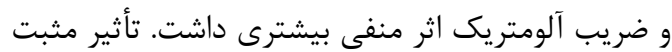
اسيد ساليسيليك در مقايسه با اسيرمين بيشتر بود.

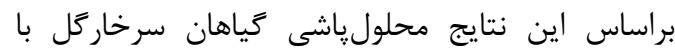

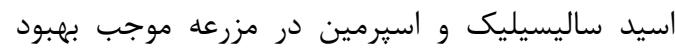

${ }^{1}$ Chojnovski and Come

${ }^{2}$ Eisvand 
Abdoli, M., and Saeidi, M. 2012. Effects of water deficiency stress during seed growth on yield and its components, germination and seedling growth parameters of some wheat cultivars. International Journal of Agriculture and Crop Sciences, 4(15): 1110-1118.

Agrawal, R. 1980. Seed technology. Oxford adnd IBH Publishing Co. LTD. New Dehli.

Askari, E., Ehsanzadeh, P., and Zenali, H. 2016. Physiological and growth responses of 12 fennel (Foeniculum valgare Mill) genotypes to water potential at seedling stage. Journal of Plant Process and Function, 4(14): 1-16. [In Persian with English Summary].

Aslani, L., Mobli, M., and Solaimani, M. 2015. Effects of different spermidine concentrations on germination of three cucumber (Cucumis sativus) cultivars under low temperature. Iranian Journal of Seed Research, 2(1): 53-63. [In Persian with English Summary].

Azimi, M. S., Daneshian, J., Sayfzadeh, S., and Zare, S. 2013. Evaluation of amino acid and salicylic acid application on yield and growth of wheat under water deficit. International Journal of Agriculture and Crop Sciences, 5(8): 816-819.

Baalibaki, R.Z., Zurayk, R.A., Bleik, M.M., and Talhouk, S.N. 1999. Germination and seedling development of drought tolerant and susceptible wheat under moisture stress. Seed Science and Technology, 27(1): 291-302.

Bachrach, U. 2005. Naturally occurring polyamines: interaction with macro-molecules. Current Protein Peptide Science, 6(6): 559-566. https://doi.org/10.2174/138920305774933240

Bajji, M., Kient, J.M., and Lutts, S. 2002. Osmotic and ionic effects of $\mathrm{NaCl}$ on germination, early seedling growth and ion content of Atriplex halimus (Chenopodiaceae). Canadian Journal of Botany, 80(3): 297-304. https://doi.org/10.1139/b02-008

Ceeh, R. 2006. Phytochemical variation within populations of Echinacea purpurea (Asteraceae). Biochemical Systematics and Ecology, 30(9): 837-854.

Chojnowski, F.C., and Come, D. 1997. Physiology and biochemical changes induced in sunflower seeds by osmopriming and drying, storage and aging. Seed Science Research, 7: 323-331. https://doi.org/10.1017/S096025850000372X

Couee, I., Hummel, I., Sulmon, C., Gouesbet, G., and EL- Amrani, A. 2004. Involvement of polyamines in root development. Plant Cell, Tissue and Organ Culture, 76(1): 1-10. https://doi.org/10.1023/A:1025895731017

Daneshmand, F., Arvin, M.J., Keramat, B., and Momeni, N. 2014. Interactive effects of salt stress and salicylic acid on germination and plant growth parameters of maize (Zea mays L.) under field conditions. Journal of Plant Process and Function, 1(1): 56-70. [In Persian with English Summary].

Datta, K.S., and Dayal, J. 1991. Studies on germination and early seedling growth of gram (Cicer arietinum L.) as affected by salinity. In: K.K., Dhir, I.S., Dua., and K S. Chark, (eds.). New Trends in Plant Physiology, 1: 273-276.

El-Tayeb, M.A. 2005. Response of barley grains to the interactive effect of salinity and salicylic acid. Plant Growth Regulators, 45(3): 215-225. https://doi.org/10.1007/s10725-005-4928-1

Eisvand, H.R., Tavakkol Afshari, R., Sharifzadeh, F., Maddah Arefi, H., and Hesamzadeh Hejazi, S.M. 2008. Improve the physiological quality of the seeds of decline in tall wheat grass (Agropyron elongatum Host) using hormonal priming for stress and non-stress conditions. Iranian Journal of Field Crop Science, 39(1): 53-65. [In Persian with English Summary].

Fariduddin, Q., Hayat, S., and Ahmad, A. 2003. Salicylic acid influences net photosynthetic rate, carboxylation efficiency, nitrate reductase activity, and seed yield in Brassica juncea. Photosynthetica, 41: 281-284. https://doi.org/10.1023/B:PHOT.0000011962.05991.6c 
Farooq, M., Shahzad, M.A., Basra, H., and Rehman, M. 2008. Seed priming with polyamines improves the germination and early seedling growth in fine rice. Journal of New Seed, 9(1): 145155. https://doi.org/10.1080/15228860802087297

Farooq, M., Wahid, A., Kobayashi, N., Fujita, D., and Basra, S. M. 2009. Plant drought stress: effects, mechanisms and management. Agronomy for Sustainable Development, 29(1): 185-212. https://doi.org/10.1051/agro:2008021

Figueroa, R., Herms, D. A., Cardina, J. and Doohan, D. 2010. Maternal environment effects on common groundsel (Senecio vulgaris) seed dormancy. Weed Science, 58(2): 160-166. https://doi.org/10.1614/WS-D-09-00006.1

Hasstrup Pedersen, L., Jorjensen, P.E., and Poulsen, I. 1993. Effect of seed vigour and dormancy on field emergence, development and grain yield of winter wheat (Triticum aestivum L.) and winter barley (Hordeum vulgare L.). Seed Science and Technology, 21(1): 159-178.

Heidari, H. 2012. Foxtail millet (Setaria italica) mother plants exposure to deficit and alternate furrow irrigation and their effect on seed germination. Annals of Biological Research, 3(6): 25592564.

Heshmat, S., Aldesuqu, A., akaria, Y., Baka, Z., and Bardees, M. 2013. Does exogenous application of kinetin and spermine mitigate the effect of seawater on yield attributes and biochemical aspects of grains? Journal of Stress Physiology and Biochemistry, 2(1): 21-34.

Hosseini, M., and Hadad Khodaparast, M.H. 2004. Effect of environmental agent on Nurozak (Salvia leriifolia Benth) germination in lab condition. Pajouhesh and Sazandegi, (10)37: 42-45. [In Persian with English Summary].

Hu, C., and Kitts, D. D. 2000. Studies on the antioxidant activity of Echinacea root extract. Journal of Agricultural Food Chemistry Abbreviation, 48(5): 1466-1472. https://doi.org/10.1021/jf990677+

Hussein, M., Nadia, M., EL-Gereadly, H.M., and EL-Desuki, M. 2006. Role of putrescine in resistance to salinity of pea plants (Pisum sativum L.). Journal of Applied Science Research, 2(9): 598-604.

International Seed Testing Association (ISTA). 2011. Handbook of vigor test methods. 2nd International Seed Testing Association, Zurich, Switzerland.

Jie, S,. Xing-Zheng, F., Ting, P., Xiao-San, H., Qi-Jun, F., and Ji-Hong, L. 2010. Spermine pretreatment confers dehydration tolerance of citrus in vitro plants via modulation of antioxidative capacity and stomatal response. Tree Physiology, 30(7): 914-922. https://doi.org/10.1093/treephys/tpq030

Jing, C., Cheng, Z., and Zhong, S. 2007. Effect of exogegenous salicylic acid on growth and H2O2metabolizing enzymes in rice seedlings under lead stress. Journal of Environmental Sciences, 19(1): 44-49. https://doi.org/10.1016/S1001-0742(07)60007-2

Kabiri, R., and Naghizadeh, M. 2015. Exogenous acetyl salicylic acid stimulates physiological changes to improve growth, yield and yield components of barley under water stress condition. Journal of Plant Physiology and Breeding, 5(1): 35-45.

Kafi, M., Eishi Rezaii, A., Hagighikhah, M., and Gorbanim, S. 2010. Effect of salinity and seed priming on germination and seedling characteristics of two medicinal citrus species. Journal of Agricultural Ecology, 2: 245-255.

Kaur-awhney, R., Tiburcio, A., Altabella, T., and Galton, W. 2003. Polyamines in plants: An overview. Journal of Cell and Molecular Biology, 2(1): 1-12. 
Khaksar, K., Badrooj, H.R., Hamidi, A., and Shiranirad, A.H. 2013. Effect of drought stress and normal irrigation on mother plant of some canola spring cultivars seedling emergence and establishment in field. Crop Production in Environmental Stress, 4(4): 63-71.

Khan, A.S., Zora, S., and Abbasi, N.A. 2007. Pre-storage putrescine application suppresses ethylene biosynthesis and retards fruit softening during low temperature storage in Angelino plum. $\begin{array}{llll}\text { Postharvest Biology } & \text { 36 }\end{array}$ https://doi.org/10.1016/j.postharvbio.2007.03.018

Khavazeh, M. 1998. Effect of salinity on germination, growth, and $\mathrm{Cl}, \mathrm{Na}$ content of four arid and desert species. M.Sc. Thesis, Isfahan University of Technology, Isfahan, Iran. [In Persian with English Summary].

Kiani, M., Bagheri, M., and Nezami, A. 1998. Lentil genotypes response using PEG 6000. Agricultural Science and Technology, 1(1): 39-59.

Liu, J.H., Kitashiba, H., Wang, J., Ban, Y., and Moriguchi, T. 2007. Polyamines and their ability to provide environmental stress tolerance to plants. Plant Biotechnology, 24(1): 117-126. https://doi.org/10.5511/plantbiotechnology.24.117

Lopez, M., Humara, J. M., Casares, A. and Majada, J.1999. The effect of temperature and water stress on laboratory germination of Eucalyptus globulus Labill. seeds of different sizes. Annals of Forest Science, 57: 245-250. https://doi.org/10.1051/forest:2000115

Maguire, J. D. 1962. Speed of germination in selection and evolution for seeding vigor. Crop Science, 2(2): 176-177. https://doi.org/10.2135/cropsci1962.0011183X000200020033x

Mashi, A., and Galeshi, S. 2007. The effect of salinity on germination indexes of four Hull-less barley genotypes. Journal of Agricultural Sciences and Natural Resources, 13(6): 45-57. [In Persian with English Summary].

Metwally, A., Finkemeier, I., Georgi, M., and Dietz, K.J. 2003. Salicylic acid alleviates the cadmium toxicity in barley seedlings. Physiology and Biochemistry of Plant, 132: 272-281. https://doi.org/10.1104/pp.102.018457

Moreno-Martiners, E., Vazquez-badillo, M. E., Rivera, A., Navarrete, R., and Esquive villargana, F. 1998. Effect of seed shape and size on germination of corn (Zea mays L.) saturated under adverse condition. Seed Science and Technologies, 26(1): 439-448.

Nemeth, M., Janda, T., Hovarth, E., Paldi, E., and Szali, G. 2002. Exogenous salicylic acid increases polyamine content but may decrease drought tolerance in maize. Plant Science, 162(4): 569-574. https://doi.org/10.1016/S0168-9452(01)00593-3

Parmoon, G.H., Ebadi, A., Ghaviazm. A., and Miri, M. 2013. Effect of seed priming on germination and seedling growth of Chamomile under salinity. Electronic Journal of Crop Production, 6(3): 145-164. [In Persian with English Summary].

Penuelas, J., Isla, R., Filella, I., and Araus, J. 1997. Visible and near-infrared reflectance assessment of salinity effects on barley. Reprinted from Crop Science, 37(1): 198-202. https://doi.org/10.2135/cropsci1997.0011183X003700010033x

Pill, W.G., and Korengle, T.K. 1997. Seed priming advance the germination of Kentuckly bluegrass

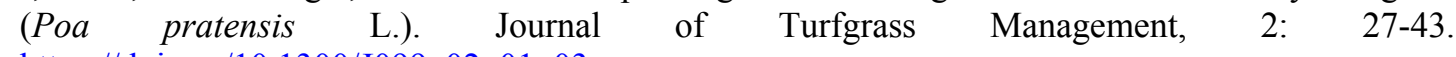
https://doi.org/10.1300/J099v02n01 03

Popova, L.P., Maslenkova, L.T., Yordanova, R.Y., Ivanova, A.P., Krantev, A P., Szalai, G., and Janda, T. 2009. Exogenous treatment with salicylic acid attenuates cadmium toxicity in pea seedlings. Plant Physiology and Biochemistry, 47(3): 224-231. https://doi.org/10.1016/j.plaphy.2008.11.007

Rajasekaran, L.R., Stiles, A., Surette, M.A., Sturz, A.V., Blake, T.J., Caldwell, C., and Nowak, J. 2002. Stand establishment technologies for processing carrots: Effects of various temperature 
regimes on germination and the role of salicylates in promoting germination at low temperatures. Canadian Journal of Plant Science, 82: 443-450. https://doi.org/10.4141/P01-016

Raskin, I. 1992. Role of salicylic acid in plants. Annual Review of Plant Physiology and Plant Molecular Biology, 43(1): 439-463. https://doi.org/10.1146/annurev.pp.43.060192.002255

Riginos, C., Heschel, M.S., and Schmitt, J. 2007. Maternal effects of drought stress and inbreeding in impatiens capensis (Balsaminaceae). American Journal of Botany, 94(12): 1984-1991. https://doi.org/10.3732/ajb.94.12.1984

Ruan, S., Xue, Q., and Tylkawska, K. 2002. The influence of priming on germination of rice (Oryza sativa L.) seeds and seedling emergence and performance in flooded soil. Seed Science and Technology, 30(1): 61-67.

Sadat Noori, A., Shiranirad, A.H., Alahdadi, I., Akbari, G.H. and Labafi Hasan Abadi, M.R. 2007. Investigation of seed vigor and germination of canola cultivars under less irrigation in padding stage and after it. Pakistan Journal of Biological Science, 10(17): 2880-2884. https://doi.org/10.3923/pjbs.2007.2880.2884

Saeidnejad, A.H., Pouramir, F., and Naghizadeh, M. 2012. Improving chilling tolerance of maize seedlings under cold conditions by spermine application. Notulae Scientia Biologicae, 4(3): 110117. https://doi.org/10.15835/nsb437554

Scott, S.J., Jones, R.A., and Williams, W.A. 1984. Review of data analyisis methods for seed germination. $\quad$ Crop $\quad$ Science, $24(6)$ : https://doi.org/10.2135/cropsci1984.0011183X002400060043x

Seyed Ahmadi, S.A. 2013. Evaluation of germination components and vigor of parent seeds canola produced from of heat and drought stress in end of the growing season. Crop Physiology Journal, 17(5): 61-75.

Shekari, F., Asadi Danalo, A., and Mustafavi, S.H. 2015. Exogenous polyamines improve seed germination of borage under salt stress via involvement in antioxidant defenses. Walia Journal, 31(6): 57-63.

Shekari, F., Baljani, R., Saba, J., Afsahi, K., and Shekari, F. 2010. Effect of seed priming with salicylic acid on growth characteristics of borage plants (Borago officinalis) seedlings. Agroecology Journal (Journal of New Agricultural Science), 6(18): 47-53. [In Persian with English Summary].

Soltani, A., Gholipoor, M., and Zeinali, E. 2006. Seed reserve utilization and seedling growth of wheat as affected by drought and salinity. Environmental and Experimental Botany, 55(1-2): 195200. https://doi.org/10.1016/j.envexpbot.2004.10.012

Verma, S., and Mishra, S.N. 2005. Putrescine alleviation of growth in salt stressed Brassica Juncea by inducing antioxidative defense system. Journal of Plant Physiology, 162(2): 669-677. https://doi.org/10.1016/j.jplph.2004.08.008

Warmazyaryan, Kh., Sohrabi, Y., and Weisani, W. 2015. Germination characteristics of seeds obtained from four chickpea (Cicer arietinum L.) cultivars under different irrigation levels. Plant Production Technology, 15(1): 87-98. [In Persian with English Summary].

Zakaria, M.S., Ashraf, H., and Serag, E.Y. 2009. Direct and residual effects of nitrogen fertilization, foliar application of potassium and plant growth retardant on Egyptian cotton growth, seed yield, seed viability and seedling vigor. Acta Ecological Sinica, 29(1): 116-123.

Zhou, X., Mackeuzie, A., Madramootoo, C., and Smith, D. 1999. Effect of stem-injected plant growth regulators with or without sucrose on grain production, biomass and photosynthetic activity of field 


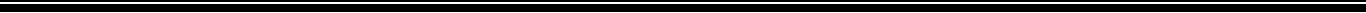

grown corn plants. Journal of Agronomy and Crop Science, 183(2): 103-110. https://doi.org/10.1046/j.1439-037x.1999.00331.x 


\title{
Effects of Foliar Application of Salicylic Acid and Spermine on Maternal Plant under Drought Stress on Germination Indices of Purple Coneflower (Echinacea purpurea)
}

\author{
Hakimeh Darvizheh ${ }^{1}$, Mortez Zahedi ${ }^{2, *}$, Bohlul Abbaszadeh ${ }^{3}$, Jamshid Razmjoo ${ }^{2}$
}

\section{Extended abstract}

Introduction: Echinacea purpurea, a member of Asteraceae family, is a herbal medicine which is effective for promoting human immune system. Enviromental stresses including water defecit, which limit maternal plant growth, can also affect their seed quality and germination. Various compounds such as salicylic acid and spermin are known to be useful in the alleviation of harmful effects of drought on plants and their seed production.

Materials and Methods: In order to investigate the seed vigor of Purple Coneflower after foliar application of salicylic acid (SA) and spermine (SPM) on maternal plant (no spray,75 mg/l SA, $150 \mathrm{mg} / \mathrm{L}$ SA, $75 \mathrm{mg} / \mathrm{L}$ SPM, $75 \mathrm{mg} / \mathrm{l} \mathrm{SA}+75 \mathrm{mg} / \mathrm{L}$ SPM and $150 \mathrm{mg} / \mathrm{L} \mathrm{SA}+75 \mathrm{mg} / \mathrm{L}$ SPM) under three irrigation regimes (irrigation after 20,40 and 60\% depletion of soil available water), a split plot experiment was conducted based on a completely randomized block design with three replications during 2016- 2017 growing seasons at research field of Institute of Forests and Rangelands, Iran.

Results: Water stress decreased the percentage and rate of germination, shoot and seedling length, shoot dry weight, germination energy and seed germination vigour. The results showed that foliar application had a significant effect on shoot, root and seedling length, shoot, root and seedling dry weight, germination rate, allometric factor, and germination vigour. The interaction effect of drought stress and foliar application indicated that non-stress and $150 \mathrm{SA}+70 \mathrm{SPM} \mathrm{mg} / \mathrm{L}$ had the highest radicle length $(28.8 \mathrm{~mm})$, radicle dry weight $(1.81 \mathrm{mg})$, seedling dry weight $(6.20 \mathrm{mg})$ and Allometric factor $(0.412)$.

Conclusions: Based on the results of the current experiment, the foliar application of salicylic acid and spermine improved the seed germination of coneflower plants under both normal and water stress conditions and the highest values of these parameters were obtained under combained application of high concentrations of salicylic acid $(150 \mathrm{mg} / \mathrm{L})$ and spermine $(75 \mathrm{mg} / \mathrm{L})$.

Keywords: Germination energy, Germination rate, Germination vigour, Allometric factor

\section{Highlights:}

1- Investigating the foliar application of salicylic acid and spermine in maternal Echinacea purpurea plant under drought stress in germination of seed.

2- The foliar application of salicylic acid and spermine on maternal plants of Echinacea improved germination quality under water stress.

\footnotetext{
${ }^{1} \mathrm{Ph} . D$. Student Department of Agronomy, Collage of Agricultural Sciences, Isfahan University of Technology, Isfahan, Iran

${ }^{2}$ Associate Professor and Professor, Department of Agronomy and Plant breeding, Collage of Agriculture, Isfahan University of Technology, Isfahan, Iran

3 Research Institute of Forests and Rangelands, Agricultural Research Education and Extension Organization (AREEO), Tehran, Iran
}

DOI: $10.29252 /$ yujs.5.1.1

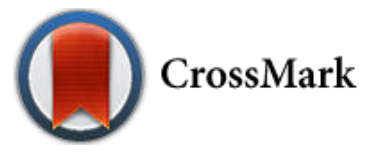

*Corresponding author, E-mail address: mzahedi@cc.iut.ac.ir 